\title{
Benefits and risks of using clopidogrel before coronary artery bypass surgery: Systematic review and meta-analysis of randomized trials and observational studies
}

\author{
Fausto Biancari, MD, PhD, ${ }^{a}$ K. E. Juhani Airaksinen, MD, PhD, ${ }^{b}$ and Gregory Y. H. Lip, MD, PhD
}

Objective: The benefits and risks associated with the use of clopidogrel before coronary artery bypass grafting are controversial, and these were investigated in the present meta-analysis.

Methods: A systematic literature search was performed to identify studies on the use of clopidogrel before coronary artery bypass grafting. Meta-analysis was performed according to the Cochrane Handbook for Systematic Reviews.

\begin{abstract}
Results: The literature search yielded 3 prospective randomized studies and 17 observational studies with valid data. Randomized studies were post hoc analyses of the Clopidogrel as Adjunctive Reperfusion Therapy (CLARITY), Clopidogrel for the Reduction of Events During Observation (CREDO), and Clopidogrel in Unstable Angina to Prevent Recurrent Ischemic Events trials. Meta-analysis based on these data showed a nonsignificant reduced risk of immediate postoperative composite end point (death, myocardial infarction, or stroke) in the clopidogrel group (risk ratio [RR], 0.77; 95\% confidence interval [CI], 0.58-1.04). Data from the CREDO and CLARITY trials showed a similar risk of death (RR, 0.81; 95\% CI, 0.20-3.37), myocardial infarction (RR, $0.58 ; 95 \%$ CI, 0.25-1.33), and major bleeding according to Thrombolysis in Myocardial Infarction criteria (RR, $1.48 ; 95 \%$ CI, 0.72-3.04). Meta-analysis of observational studies showed that preoperative exposure to clopidogrel was associated with an increased risk of death (RR, 1.30; 95\% CI, 1.02-1.67), reoperation for bleeding (RR, 1.88; 95\% CI, 1.37-2.58), blood loss (mean difference, $157.8 \mathrm{~mL} ; 95 \% \mathrm{CI}, 61.9-253.6$ ), need of packed red blood cell transfusion (RR, $1.23 ; 95 \%$ CI, 1.10-1.37), and increased use of blood products. A significantly reduced risk of postoperative myocardial infarction was observed among patients taking clopidogrel (RR, 0.63; 95\% CI, 0.48-0.82).
\end{abstract}

Conclusions: Contrary to the findings of post hoc analyses of randomized trials, observational studies showed that recent exposure to clopidogrel before coronary artery bypass grafting is associated with increased risk of postoperative death, reoperations for bleeding, blood loss, and need of blood transfusions. (J Thorac Cardiovasc Surg 2012;143:665-75)

\section{Supplemental material is available online.}

Current guidelines for the management of acute coronary syndrome recommend upstream use of dual antiplatelet therapy with clopidogrel and aspirin before diagnostic coronary angiography. ${ }^{1,2}$ Upstream loading with clopidogrel may be beneficial in elective percutaneous coronary

\footnotetext{
From the Division of Cardiothoracic and Vascular Surgery, ${ }^{\mathrm{a}}$ Department of Surgery, Oulu University Hospital, Oulu, Finland; Division of Cardiology, ${ }^{\mathrm{b}}$ Department of Internal Medicine, Turku University Hospital, Turku, Finland; and University of Birmingham Centre for Cardiovascular Sciences, ${ }^{c}$ City Hospital, Birmingham, England.

Disclosures: Authors have nothing to disclose with regard to commercial support.

Received for publication Oct 26, 2010; revisions received Jan 4, 2011; accepted for publication Jan 25, 2011; available ahead of print June 27, 2011.

Address for reprints: Fausto Biancari, MD, PhD, Division of Cardiothoracic and Vascular Surgery, Department of Surgery, Oulu University Hospital, PO Box 21, 90029 Oulu, Finland (E-mail: faustobiancari@yahoo.it).

$0022-5223 / \$ 36.00$

Copyright (C) 2012 by The American Association for Thoracic Surgery

doi:10.1016/j.jtcvs.2011.01.069
}

interventions ${ }^{3}$ and is commonly used in clinical practice. Despite the proven benefits of dual antiplatelet treatment in these settings, cardiac surgeons frequently face a possible increased risk of bleeding and resternotomy in patients undergoing coronary artery bypass grafting (CABG) early after diagnostic coronary angiography or failed percutaneous coronary intervention. Although it may be advisable to withhold clopidogrel administration in patients who are likely to require $\mathrm{CABG}$, there are no reliable predictors for the need of CABG before diagnostic coronary angiography. ${ }^{4}$

After a decade of widespread use of clopidogrel before urgent/emergency CABG, the potential benefits and risks associated with preoperative dual antiplatelet regimen in surgical patients are still controversial. We hypothesized that the trends toward reduced cardiovascular complications in limited data from post hoc analyses of clinical trials may not be evident in clinical practice. We performed the present systematic review and meta-analysis to address this hypothesis. 


\begin{aligned} & \multicolumn{2}{|c|}{ Abbreviations and Acronyms } \\ & CABG $=$ coronary artery bypass grafting \\ & CI confidence interval \\ & CLARITY = Clopidogrel as Adjunctive \\ & Reperfusion Therapy \\ & CREDO $=$ Clopidogrel for the Reduction of \\ & Events During Observation \\ & CURE $=$ Clopidogrel in Unstable Angina to \\ & Prevent Recurrent Ischemic Events \\ & RR $=$ risk ratio \\ & TIMI $=$ Thrombolysis in Myocardial \\ & Infarction \end{aligned}

\section{MATERIALS AND METHODS}

This meta-analysis was performed in accordance with the Cochrane Handbook for Systematic Reviews. ${ }^{5}$ Reference search was performed through PubMed, Cochrane Library, and Scopus up to July 1, 2010, for studies evaluating the combination of clopidogrel and aspirin versus aspirin alone in patients undergoing CABG. The words used in the search were clopidogrel, coronary artery bypass surgery, coronary artery bypass grafting, surgical, and revascularization.

Studies in which none of the control patients received aspirin were excluded from this analysis. Moreover, we excluded those studies in which most of the control patients had been exposed to clopidogrel even if the drug was discontinued 5 to 7 days before surgery, because the latter may introduce a bias in terms of indication for urgent surgery ${ }^{6,7}$ and affect the outcome end points. We also excluded those studies reporting use of aprotinin in more than $10 \%$ of patients because this drug may reduce hemorrhagic complications in these patients and significantly increase the mortality risk. ${ }^{8}$ Studies including patients undergoing procedures other than isolated $\mathrm{CABG}$ were excluded from this analysis.

Prospective, randomized studies of patients undergoing isolated CABG with allocation to preoperative use of clopidogrel or placebo in addition to aspirin were included at first in this analysis. In the present analysis, we included only patients who underwent CABG during the initial hospitalization because delayed surgery may introduce a bias of late exposure and discontinuation to clopidogrel. Clinical variables and outcome end points were reported as originally defined by the authors. For the second step, we performed a meta-analysis of observational studies on this topic.

No extramural funding was used to support this work. The authors are solely responsible for the design and conduct of this study, all study analyses, the drafting and editing of the article, and its final contents.

\section{Data Collection and Assessment of Data Quality}

Two authors (F.B., K.E.J.A.) independently abstracted data from all eligible studies using an Excel file (Microsoft Corp, Redmond, Wash). We retrieved data on study design, study size, patient demographics, and any major outcome end points. Data were retrieved from the articles, and an attempt was made to retrieve missing data only from the authors of prospective, randomized studies.

The risk of bias possibly affecting prospective, randomized studies has been assessed independently by the authors (F.B., K.E.J.A.) and reviewed by one author (F.B.) according to the Cochrane Collaboration criteria for assessing risk of bias. ${ }^{5}$ Disagreement has been resolved by consensus. Trials that met eligibility criteria have been assessed for generation of random allocation sequence, allocation concealment, blinding of intervention, incomplete outcome data, freedom of selective reporting, and freedom of other biases. These parameters were categorized as yes, unclear, or no.
The quality of observational, cohort studies was assessed with the Newcastle-Ottawa Scale, which is a 9-point scale that assigns points on the basis of the process of selection ( $0-4$ points), comparability ( $0-2$ points), and identification of the outcomes of study participants ( $0-3$ points) in cohort studies. ${ }^{9}$

\section{Outcomes of Interest}

The outcome end points evaluated in this analysis were cardiovascular death, myocardial infarction, stroke, or a combination of the latter adverse events; major bleeding as defined by Thrombolysis in Myocardial Infarction (TIMI) criteria ${ }^{10}$; need of reoperation for bleeding; postoperative blood loss; need of packed red blood cells transfusion; and the amount of units of packed red blood cells, fresh-frozen plasma, and platelets transfused. Renal failure was not considered as an outcome of interest because the definition of this end point may vary markedly.

\section{Statistical Analysis}

Meta-analysis was performed using Review Manager 5.0.18 (Copenhagen: The Nordic Cochrane Centre, The Cochrane Collaboration, 2008). Risk of adverse event is expressed as risk ratio (RR) with $95 \%$ confidence interval (CI). Continuous variables were reported as weighted mean differences and $95 \%$ CI. Heterogeneity was assessed by using the $\mathrm{I}^{2}$ statistic. $\mathrm{I}^{2}$ less than $40 \%$ has been considered as an unimportant heterogeneity. In case of important heterogeneity, we have used the random-effects model.

Analyses were initially performed separately for randomized trials and observational studies because of the distinct nature of these studies. A pooled analysis of all studies was then performed. We did not perform meta-regression analysis because of the small number of studies included.

\section{RESULTS}

\section{Search Results of Prospective, Randomized Studies}

The literature search of prospective, randomized studies initially yielded 21 articles that were pertinent to this issue and potentially being prospective and randomized trials. The literature search flowchart is shown in Figure 1. A search in Clinicaltrials.gov yielded no studies dealing with preoperative use of clopidogrel plus aspirin versus aspirin alone before $\mathrm{CABG}$ surgery.

Overall, only 3 prospective, randomized studies ${ }^{11-13}$ were available for data retrieval and meta-analysis. The reasons for excluding the other studies are reported in detail in Table E1. The included studies were post hoc analyses of 3 large prospective randomized trials ${ }^{11-13}$; thus, allocation into the revascularization subgroups was not randomized, and a potential bias may exist. However, clopidogrel was administered in a randomized and blinded fashion, and any bias at allocation may be balanced between the clopidogrel and control groups. These post hoc analyses included $3.9 \%{ }^{11,12}$ to $8.1 \%{ }^{13}$ of the initially enrolled patients. Characteristics of these studies are summarized in Table 1. Risk of bias of these trials is reported in Table 2.

\section{Description of Prospective, Randomized Studies Clopidogrel as Adjunctive Reperfusion Therapy-TIMI} 28 trial. The Clopidogrel as Adjunctive Reperfusion Therapy (CLARITY)-TIMI 28 trial was carried out at 319 sites in 23 countries between 2003 and $2004 .{ }^{14}$ The trial 


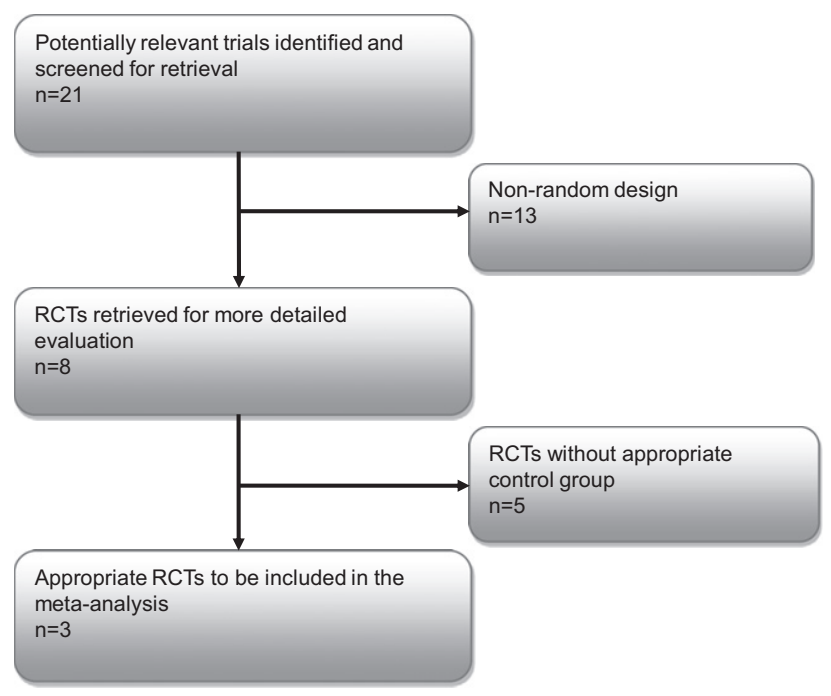

FIGURE 1. Literature search and study selection of randomized controlled trials. RCT, Randomized controlled trial.

enrolled 3491 patients with ST-elevation myocardial infarction who were scheduled to receive a fibrinolytic agent, an anticoagulant (if a fibrin-specific lytic agent was prescribed), and aspirin. Patients were randomly assigned to receive either clopidogrel (300-mg loading dose followed by $75 \mathrm{mg} / \mathrm{d}$ ) or placebo in a double-blind fashion. Patients were to receive study medication daily up to and including the day of coronary angiography. For patients who did not undergo angiography, the study drug was to be administered up to and including day 8 or hospital discharge, whichever came first. All patients were to be treated with a fibrinolytic agent, aspirin 150 to $325 \mathrm{mg}$ on the first day and 75 to 162 $\mathrm{mg} / \mathrm{d}$ thereafter, and for those receiving a fibrin-specific lytic agent, heparin for 48 hours. CLARITY trialists reported the results of a post hoc analysis of 136 patients (66 in the clopidogrel group and 70 in the control group) who underwent CABG a median of 8 days after randomization and 4 days from coronary angiography. ${ }^{12}$ Study medication was interrupted a median of 5 days before CABG.

Clopidogrel for the Reduction of Events During Observation trial. The Clopidogrel for the Reduction of Events During Observation (CREDO) $)^{3}$ trial was a randomized, double-blind, placebo-controlled trial conducted among 2116 patients who were to undergo elective percutaneous coronary intervention or deemed at high likelihood of undergoing percutaneous coronary intervention, enrolled at 99 centers in North America from 1999 to 2001. Patients were randomly assigned to receive clopidogrel $300 \mathrm{mg}$ $(n=1053)$ or placebo $(n=1063) 3$ to 24 hours before percutaneous coronary intervention. Thereafter, all patients received clopidogrel, $75 \mathrm{mg} / \mathrm{d}$, through day 28 . From day 29 to 12 months, patients in the loading-dose group received clopidogrel, $75 \mathrm{mg} / \mathrm{d}$, and those in the control group received placebo. Both groups received aspirin throughout the study.
Forty-one patients in the clopidogrel group and 42 patients in the control group underwent CABG during the same hospitalization and were included in a post hoc analysis. ${ }^{13}$

Clopidogrel in Unstable Angina to Prevent Recurrent Ischemic Events trial. The Clopidogrel in Unstable Angina to Prevent Recurrent Ischemic Events (CURE) trial was a randomized, double-blind, placebo-controlled trial comparing clopidogrel with placebo in 12,562 patients presenting with non-ST-elevation myocardial infarction. ${ }^{15} \mathrm{~Pa}-$ tients were recruited from December 1998 to September 2000 at 428 centers in 28 countries. All patients received aspirin $75 \mathrm{mg}$ to $325 \mathrm{mg}$. Patients were randomly assigned to clopidogrel (loading dose of $300 \mathrm{mg}$ orally and then $75 \mathrm{mg}$ daily) or matching placebo on a double-blind basis and continued for 3 to 12 months.

Of the 12,562 randomized patients, 2072 (16.5\%) underwent $\mathrm{CABG}$ and were the subjects of a post hoc analysis. ${ }^{11}$ A total of 1015 patients (530 placebo- and 485 clopidogreltreated patients) underwent surgical revascularization during the initial hospitalization after a median of 12 to 13 days and are included in the present analysis. For patients proceeding to $\mathrm{CABG}$, the timing of discontinuation of clopidogrel and aspirin was at the discretion of the surgeon and local treatment policy. The other patients were excluded from the analysis because of the long median period from randomization to surgery (67.5-73.0 days) and because these patients discontinued the study drug for a median of 17 days before surgery.

\section{Pooled Outcome of Prospective, Randomized Studies}

We requested supplemental data from the trials' principal investigators, and the only data were provided from the CREDO trialists. Data on composite end point (death, myocardial infarction, or stroke) at 30 days were available from the CREDO and CLARITY trials, whereas we extracted the data of the CURE study from the hazard rate curve of patients who underwent surgery during index hospitalization. The authors stated that the median time from randomization to surgery was 12 days ${ }^{11}$; therefore, we extracted the composite end point rates at 30 days since the median time to CABG. Fixed effect analysis showed that there was a nonsignificant trend toward a reduced risk of composite end point in the clopidogrel group (RR, $0.77 ; 95 \% \mathrm{CI}, 0.58$ 1.04; $\mathrm{I}^{2}=0 \%$; Figure 2).

Data from CREDO and CLARITY showed similar immediate postoperative mortality (RR, $0.81 ; 95 \%$ CI, 0.20 $3.37 ; \mathrm{I}^{2}=0 \%$ ) and myocardial infarction (RR, $0.58 ; 95 \%$ CI, $0.25-1.33 ; \mathrm{I}^{2}=0 \%$ ), but still in favor of clopidogreltreated patients. No postoperative stroke was observed in both these studies. Data from the CREDO and CLARITY trials showed a similar risk of major bleeding according to TIMI criteria (RR, $1.48 ; 95 \% \mathrm{CI}, 0.72-3.04 ; \mathrm{I}^{2}=0 \%$ ) in the clopidogrel and control groups. Only the CLARITY study reported on the rate of reoperation for bleeding, which 
TABLE 1. Characteristics of randomized trials included in meta-analysis

\begin{tabular}{|c|c|c|c|c|c|}
\hline Study & Population & Participants & Methods & $\begin{array}{c}\text { Available outcomes } \\
\text { of interest of the } \\
\text { present study } \\
\end{array}$ & Source of funding \\
\hline CLARITY & $\begin{array}{l}\text { Ischemic discomfort at } \\
\text { rest within } 12 \mathrm{~h} \text { before } \\
\text { randomization that } \\
\text { lasted more than } 20 \\
\text { min; if patients had ST- } \\
\text { segment elevation of at } \\
\text { least } 0.1 \mathrm{mV} \text { in at least } 2 \\
\text { contiguous limb leads, } \\
\text { ST-segment elevation } \\
\text { of at least } 0.2 \mathrm{mV} \text { in at } \\
\text { least } 2 \text { contiguous } \\
\text { precordial leads, or left } \\
\text { bundle-branch block } \\
\text { that was not known to } \\
\text { be old; and if they were } \\
\text { scheduled to receive } \\
\text { a fibrinolytic agent, an } \\
\text { anticoagulant (if } \\
\text { a fibrin-specific lytic } \\
\text { agent was prescribed), } \\
\text { and aspirin. }\end{array}$ & $\begin{array}{l}136 \text { patients who } \\
\text { underwent CABG } \\
\text { This trial enrolled initially } \\
3491 \text { patients. }\end{array}$ & $\begin{array}{l}\text { Prospective, randomized } \\
\text { double-blind, placebo } \\
\text { controlled, multicenter } \\
\text { trial. Post hoc analysis } \\
\text { A total of } 66 \text { patients } \\
\text { received clopidogrel } \\
300-\mathrm{mg} \text { loading dose } \\
\text { followed by } 75 \mathrm{mg} / \\
\text { d before CABG. } \\
\text { A total of } 70 \text { patients } \\
\text { received placebo before } \\
\text { CABG. } \\
\text { All patients received } \\
\text { a fibrinolytic agent, } \\
\text { aspirin } 150-325 \mathrm{mg} \text { on } \\
\text { the first day and } 75-162 \\
\text { mg daily thereafter, and } \\
\text { for those receiving } \\
\text { a fibrin-specific lytic } \\
\text { agent, heparin for } 48 \mathrm{~h} \text {. }\end{array}$ & $\begin{array}{l}\text { 30-d cardiovascular death, } \\
\text { myocardial infarction, } \\
\text { stroke, TIMI, major } \\
\text { bleeding, and } \\
\text { composite end point } \\
\text { (cardiovascular death, } \\
\text { myocardial infarction, } \\
\text { or stroke)* }\end{array}$ & $\begin{array}{l}\text { Supported in part by } \\
\text { Sanofi-Synthelabo } \\
\text { (Paris, France)/ } \\
\text { Bristol-Myers Squibb } \\
\text { (New York, NY) }\end{array}$ \\
\hline CREDO & $\begin{array}{l}\text { Patients with symptomatic } \\
\text { coronary artery disease } \\
\text { with objective evidence } \\
\text { of ischemia referred for } \\
\text { or thought to be at high } \\
\text { likelihood for requiring } \\
\text { percutaneous coronary } \\
\text { intervention. }\end{array}$ & $\begin{array}{l}83 \text { patients who } \\
\text { underwent CABG } \\
\text { without index } \\
\text { percutaneous coronary } \\
\text { intervention } \\
\text { This trial enrolled initially } \\
2116 \text { patients. }\end{array}$ & $\begin{array}{l}\text { Prospective, randomized } \\
\text { double-blind, placebo } \\
\text { controlled, multicenter } \\
\text { trial; post hoc analysis } \\
\text { A total of } 41 \text { patients } \\
\text { received clopidogrel } \\
300 \mathrm{mg} \text { and aspirin } 325 \\
\text { mg before planned } \\
\text { percutaneous coronary } \\
\text { intervention. } \\
\text { A total of } 42 \text { control } \\
\text { patients received } \\
\text { placebo and aspirin } 325 \\
\text { mg before planned } \\
\text { percutaneous coronary } \\
\text { intervention. } \\
\text { All patients received both } \\
\text { clopidogrel } 75 \text { mg/d } \\
\text { and aspirin } 325 \text { mg/d } \\
\text { until day } 28 \text { after } \\
\text { percutaneous coronary } \\
\text { intervention (treatment } \\
\text { of patients undergoing } \\
\text { CABG unknown). }\end{array}$ & $\begin{array}{l}\text { 28-d cardiovascular death, } \\
\text { myocardial infarction, } \\
\text { stroke, TIMI, major } \\
\text { bleeding, and } \\
\text { composite end point } \\
\text { (cardiovascular death, } \\
\text { myocardial infarction, } \\
\text { or stroke) }\end{array}$ & $\begin{array}{l}\text { Sanofi-Synthelabo/ } \\
\text { Bristol-Myers Squibb }\end{array}$ \\
\hline
\end{tabular}


TABLE 1. Continued

\begin{tabular}{|c|c|c|c|c|c|}
\hline Study & Population & Participants & Methods & $\begin{array}{c}\text { Available outcomes } \\
\text { of interest of the } \\
\text { present study }\end{array}$ & Source of funding \\
\hline CURE & $\begin{array}{l}\text { Patients with acute } \\
\text { coronary syndrome } \\
\text { within the preceding } 24 \\
\mathrm{~h} \text { in the absence of ST- } \\
\text { elevation of }>1 \mathrm{~mm} \text { on } \\
\text { the electrocardiogram. } \\
\text { Other supporting evidence } \\
\text { of myocardial ischemia } \\
\text { was required in the } \\
\text { form of } \\
\text { electrocardiogram } \\
\text { criteria or elevated } \\
\text { cardiac enzymes at } \\
\text { least twice the upper } \\
\text { limit of normal. }\end{array}$ & $\begin{array}{l}1015 \text { patients who } \\
\text { underwent } \mathrm{CABG} \\
\text { during index } \\
\text { hospitalization } \\
\text { This trial initially enrolled } \\
\text { 12,562 patients. }\end{array}$ & $\begin{array}{l}\text { Prospective, randomized } \\
\text { double-blind, placebo- } \\
\text { controlled, multicenter } \\
\text { trial; post hoc analysis. } \\
\text { A total of } 485 \text { patients } \\
\text { received a loading dose } \\
\text { of clopidogrel } 300 \mathrm{mg} \\
\text { followed by clopidogrel } \\
75 \mathrm{mg} / \mathrm{d} \text { plus aspirin } \\
75-325 \mathrm{mg} / \mathrm{d} \text { before } \\
\text { CABG during index } \\
\text { hospitalization. } \\
\text { A total of } 530 \text { patients } \\
\text { received placebo and } \\
\text { aspirin } 75-325 \mathrm{mg} / \mathrm{d} \\
\text { before CABG during }\end{array}$ & $\begin{array}{l}\text { Immediate postoperative } \\
\text { composite end point } \\
\text { (cardiovascular death, } \\
\text { myocardial infarction, } \\
\text { or stroke) }\end{array}$ & $\begin{array}{l}\text { Sanofi-Synthelabo/ } \\
\text { Bristol-Myers Squibb }\end{array}$ \\
\hline
\end{tabular}

*This composite end point included cardiovascular death, recurrent myocardial infarction, and recurrent ischemia requiring urgent revascularization. Because no stroke occurred in both study groups and recurrent ischemia requiring urgent revascularization was likely myocardial infarction, we have considered cardiovascular death, myocardial infarction, or stroke as composite end point.

was $6.7 \%$ in the clopidogrel group and $14.3 \%$ in the control group $(P=.43)$. The rate of reoperation for bleeding in patients stopping study medication 5 days or less before surgery was $11.4 \%$ in the clopidogrel group and $10.5 \%$ in the control group $(P=1.00)$.

\section{Search Results and Pooled Outcome of Observational Studies}

The search of observational studies initially yielded 40 articles that were pertinent to this issue and potentially evaluating the impact of preoperative use of clopidogrel before CABG. Seventeen studies ${ }^{\mathrm{E} 1-\mathrm{E} 17}$ were found to provide valid data for this meta-analysis. The literature search flowchart for observational studies is shown in Figure 3.

The main characteristics of these studies and their grading according to the Newcastle-Ottawa Scale are summarized in Table 3. Only 2 studies had comparable cohorts according to the Newcastle-Ottawa Scale criteria. All studies but one included patients exposed to clopidogrel 7 days or less before surgery, and 8 studies included patients in whom clopidogrel was stopped 5 days or less before surgery.
Exposure to clopidogrel during the immediate preoperative period was associated with an increased risk of death (13 studies including 12,129 patients: RR, 1.30; 95\% CI, 1.02-1.67; Figure 4), reoperation for bleeding (RR, 1.88; 95\% CI, 1.37-2.58; Figure 5), blood loss (mean difference, $157.8 \mathrm{~mL}$; 95\% CI, 61.9-253.6; Figure 6), need of packed red blood cell transfusion (RR, 1.23; 95\% CI, 1.10-1.37; Figure 7), and amount of packed red blood cells (mean difference, 0.77 units; $95 \% \mathrm{CI},-0.05$ to 1.59 ), fresh-frozen plasma (mean difference, 0.35 units; 95\% CI, 0.22-0.49), and platelets (mean difference, 2.41 units; $95 \% \mathrm{CI},-0.03$ to 4.86 ) transfused. A significantly reduced risk of postoperative myocardial infarction was observed among patients receiving clopidogrel (RR, $0.63 ; 95 \%$ CI, 0.48-0.82; Figure 8), whereas this drug was not associated with any benefit or harm in terms of postoperative stroke (RR, 1.26; 95\% CI, 0.78-2.02).

Inclusion in the analysis of observational studies evaluating emergency cases resulted in a slightly, nonsignificant increase of the risk of immediate postoperative death in patients exposed preoperatively to clopidogrel (RR, 1.24;

TABLE 2. Risk of bias of prospective, randomized trials included in this meta-analysis

\begin{tabular}{llccccc}
\hline Study & Sequence generation & $\begin{array}{c}\text { Allocation } \\
\text { concealment }\end{array}$ & Blinding & $\begin{array}{c}\text { Incomplete outcome data } \\
\text { addressed }\end{array}$ & $\begin{array}{c}\text { Free of selective } \\
\text { reporting }\end{array}$ & $\begin{array}{c}\text { Free of other } \\
\text { biases }\end{array}$ \\
\hline CLARITY & $\begin{array}{c}\text { Central, computerized } \\
\text { randomization }\end{array}$ & No & Yes & No & Yes & No \\
CREDO & $\begin{array}{l}\text { Randomization in blocks of } 2 \\
\text { CURE }\end{array}$ & No & Yes & Yes & Yes & No \\
& $\begin{array}{l}\text { Central, computerized } \\
\text { randomization }\end{array}$ & No & Yes & Unclear & No \\
\hline
\end{tabular}




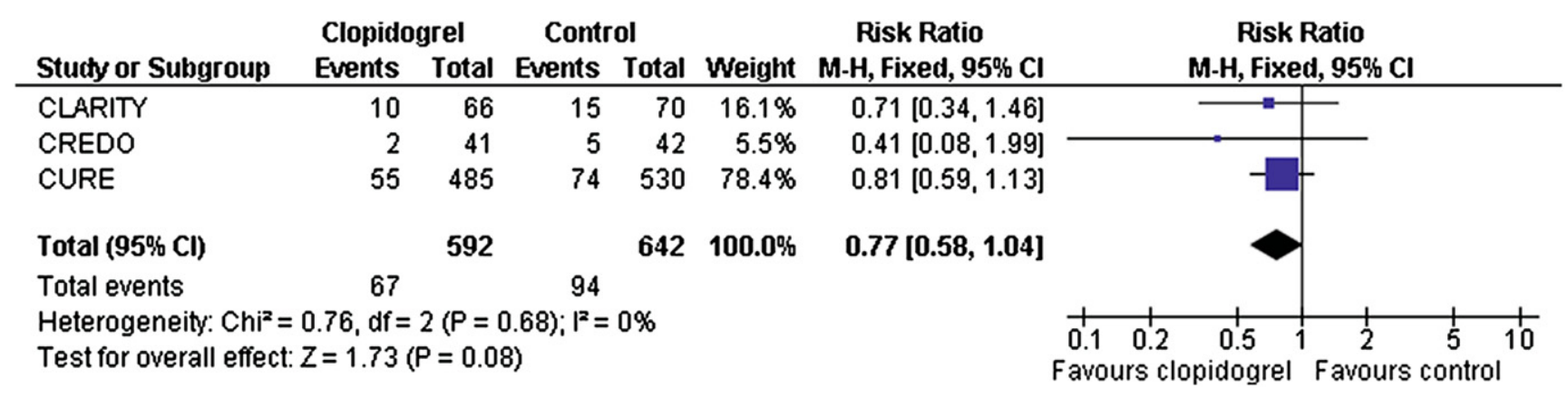

FIGURE 2. Risk of 30-day postoperative composite cardiovascular event (cardiovascular death, myocardial infarction, or stroke) in patients who received clopidogrel versus placebo before CABG. Only data from post hoc analysis of prospective randomized trials are included in this analysis. CLARITY, Clopidogren as Adjunctive Reperfusion Therapy; $C R E D O$, Clopidogrel for the Reduction of Events During Observation; CURE, Clopidogrel in Unstable Angina to Prevent Recurrent Ischemic Events; $C I$, confidence interval.

95\% CI, 0.95-1.61). The risk of resternotomy for bleeding was also increased in those studies excluding emergency cases (RR, 3.10; 95\% CI, 1.52-6.34).

When data from the CLARITY and CREDO studies were included in the analysis of observational studies, clopidogrel was still associated with increased postoperative death (RR, 1.28; 95\% CI, 1.00-1.64) and reduced risk of postoperative myocardial infarction (RR, $0.63 ; 95 \%$ CI, 0.490.81 ).

Data from 627 patients included in 2 prospective studies (CLARITY, CREDO) and 2 observational studies fulfilling Newcastle-Ottawa criteria of group comparability showed a nonsignificant trend toward increased risk of

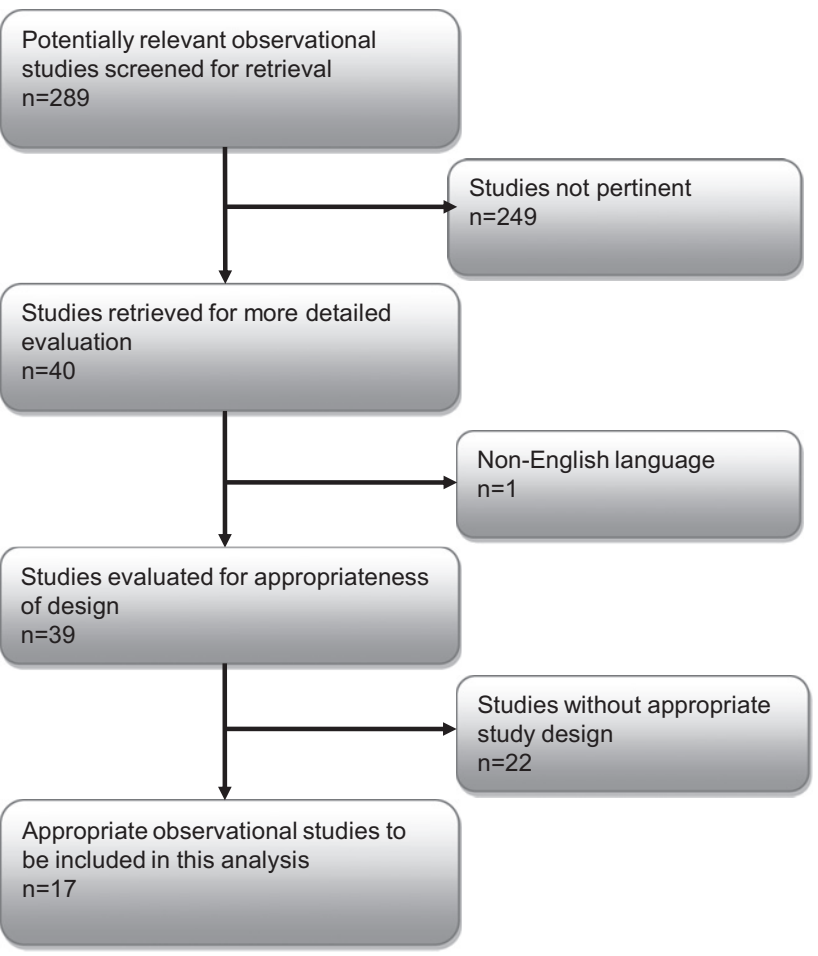

FIGURE 3. Literature search and study selection of observational studies. postoperative death with the use of clopidogrel (RR, 1.51; 95\% CI, 0.64-3.54).

Patients in whom clopidogrel was withheld 4 days or less before surgery were shown to have an increased risk of blood loss (mean difference, $87.8 \mathrm{~mL} ; 95 \%$ CI, 48.0128.6) and a trend for increased risk of resternotomy for bleeding (RR, 2.76; 95\% CI, 0.55-13.76). However, these findings are biased by the small number of patients exposed to clopidogrel (113 patients and 140 patients, respectively). Among these studies, no data were available for analysis of the other outcome end points.

\section{DISCUSSION}

The results of this systematic review and meta-analysis indicate that the current knowledge on the impact of preoperative use of clopidogrel on outcome after CABG is based on only a few studies of suboptimal quality. The lack of prospective randomized studies on this topic is of particular relevance. Indeed, we were able to identify and include in the present meta-analysis only post hoc analyses of 3 large prospective randomized trials. Thus, allocation into the revascularization subgroups was not randomized, and a potential bias may exist. However, clopidogrel was administered in a randomized and blinded fashion, and any bias at allocation should be balanced between the clopidogrel and control groups. ${ }^{13}$ These studies included only $3.9 \%$ to $8.1 \%$ of the initially enrolled patient populations in the main trials. ${ }^{12,13}$ Furthermore, details on the timing of clopidogrel discontinuation were not recorded at the time of the original trials.

Most of the available studies on this issue are retrospective analyses, and only 7 studies (despite the inappropriate study design of some of these) used propensity score analysis (Table E2), which may reduce the impact of confounding in the estimation of causal treatment effects with nonrandomized data. This is of particular concern in clopidogrel-exposed patients because their characteristics may significantly differ from those who did not receive 
TABLE 3. Characteristics and Newcastle-Ottawa quality assessment of observational studies on the use of clopidogrel before coronary artery bypass surgery included in this meta-analysis Study Clopidogrel Emergency stopped before cases Outcome not

Assessment Follow-up Adequacy of

design Control Clopidogrel surgery (d) included Representativeness Selection of exposure start of study Comparability of outcome long enough follow-up

Ascione and colleagues design Control Clopidogret

Chen and colleagues

Chen and cotc

है $\quad 2004^{\mathrm{E} 3}$

Ebrahimi and colleagues $\quad P$

$2009^{\mathrm{E} 4}$

Filsoufi and colleagues

$2008^{\mathrm{E} 5}$

Gansera and colleagues

R 246

$2003^{\mathrm{E} 6}$

อิ. Hongo and colleagues

$$
2002^{\mathrm{E} 7}
$$

气. Kang and colleagues

$2007^{\mathrm{E} 8 *}$

Karabulut and colleagues P 1580

$2004^{\mathrm{E} 9}$

Kim and colleagues $2008^{\mathrm{E} 10}$

Leong and colleagues $2005^{\text {E11 }}$

Maltais and colleagues $2008^{\mathrm{E} 12}$

Mehta and colleagues $2006^{\mathrm{E} 13}$

$\bigodot \quad$ Mengistu and colleagues $\quad \mathrm{P} \quad 50$ $2010^{\mathrm{E} 14}$

2 Nurozler and colleagues

E $2005^{\mathrm{E} 15}$

Vaccarino and colleagues P 176

$2009^{\mathrm{E} 16}$

官

$\begin{array}{llllll}\text { Woo and colleagues } & R & 63 & 15 & \leq 4 & \text { Not stated }\end{array}$

$2003^{\mathrm{E} 17}$

$P$, Prospective study; $R$, retrospective study. *Some $87 \%$ of patients had clopidogrel discontinued $\leq 5 \mathrm{~d}$ before surgery.

\section{ACD}


Clopidogrel Control Risk Ratio

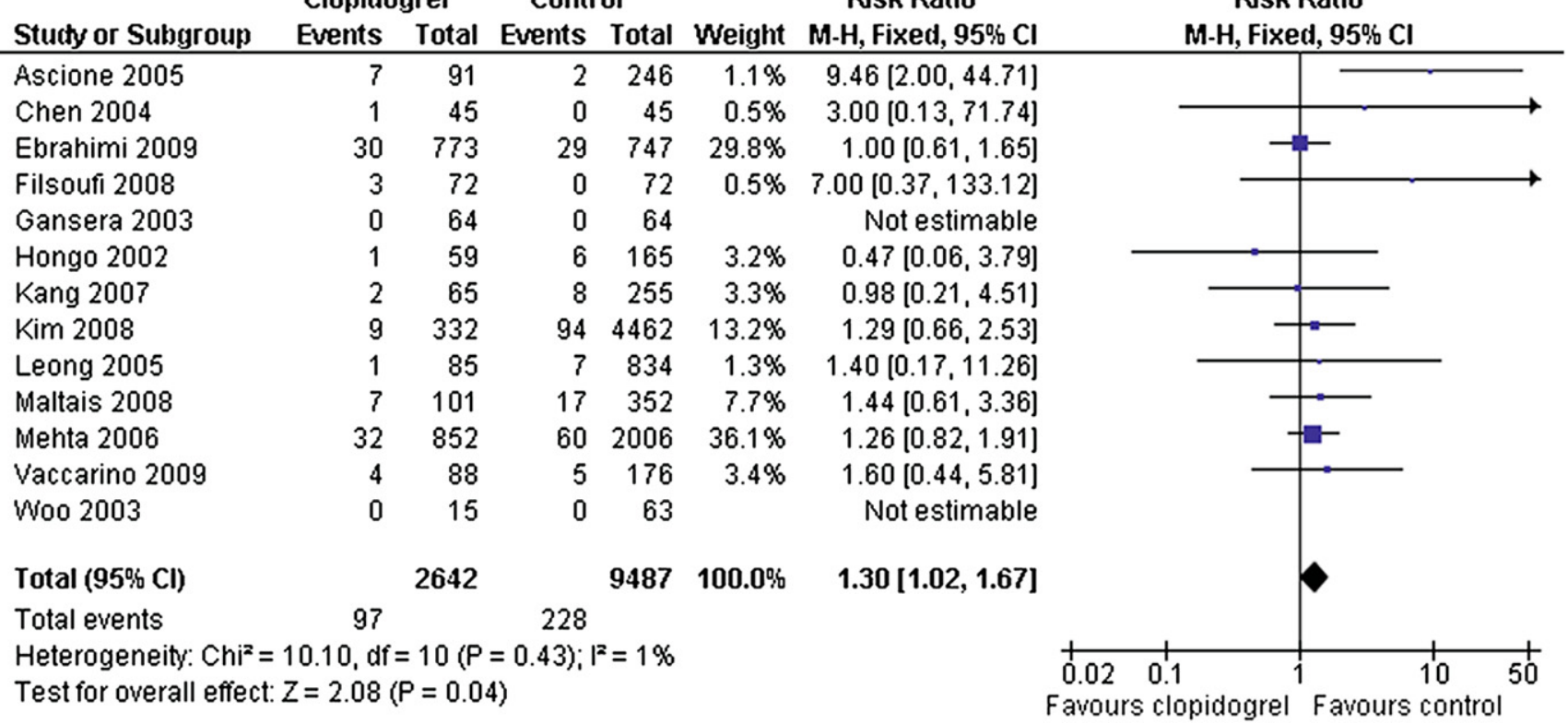

FIGURE 4. Pooled RR of immediate postoperative death in patients who received clopidogrel before CABG versus controls (observational cohort studies only included). $C I$, Confidence interval.

clopidogrel before surgery. Furthermore, although propensity score matching is commonly used, it is frequently used with inappropriate statistical methods. ${ }^{16}$ Indeed, we were able to identify only 4 studies that used propensity score matching in patients treated with clopidogrel before $\mathrm{CABG},{ }^{7,17-19}$ one being a post hoc analysis of a larger retrospective study ${ }^{18}$ (Table E2). Two studies ${ }^{17,19}$ reported data on these propensity-matched pairs, and only the study by Vaccarino and colleagues ${ }^{17}$ had a valid study design according to the present meta-analysis inclusion criteria. All these propensity-matched studies were of poor methodological quality as assessed by Austin's criteria ${ }^{16}$ (Table E2). Furthermore, only one study provided data from multiple, variable matched controls. ${ }^{20}$ Thus, any results from these studies cannot be considered conclusive because of suboptimal study design issues.

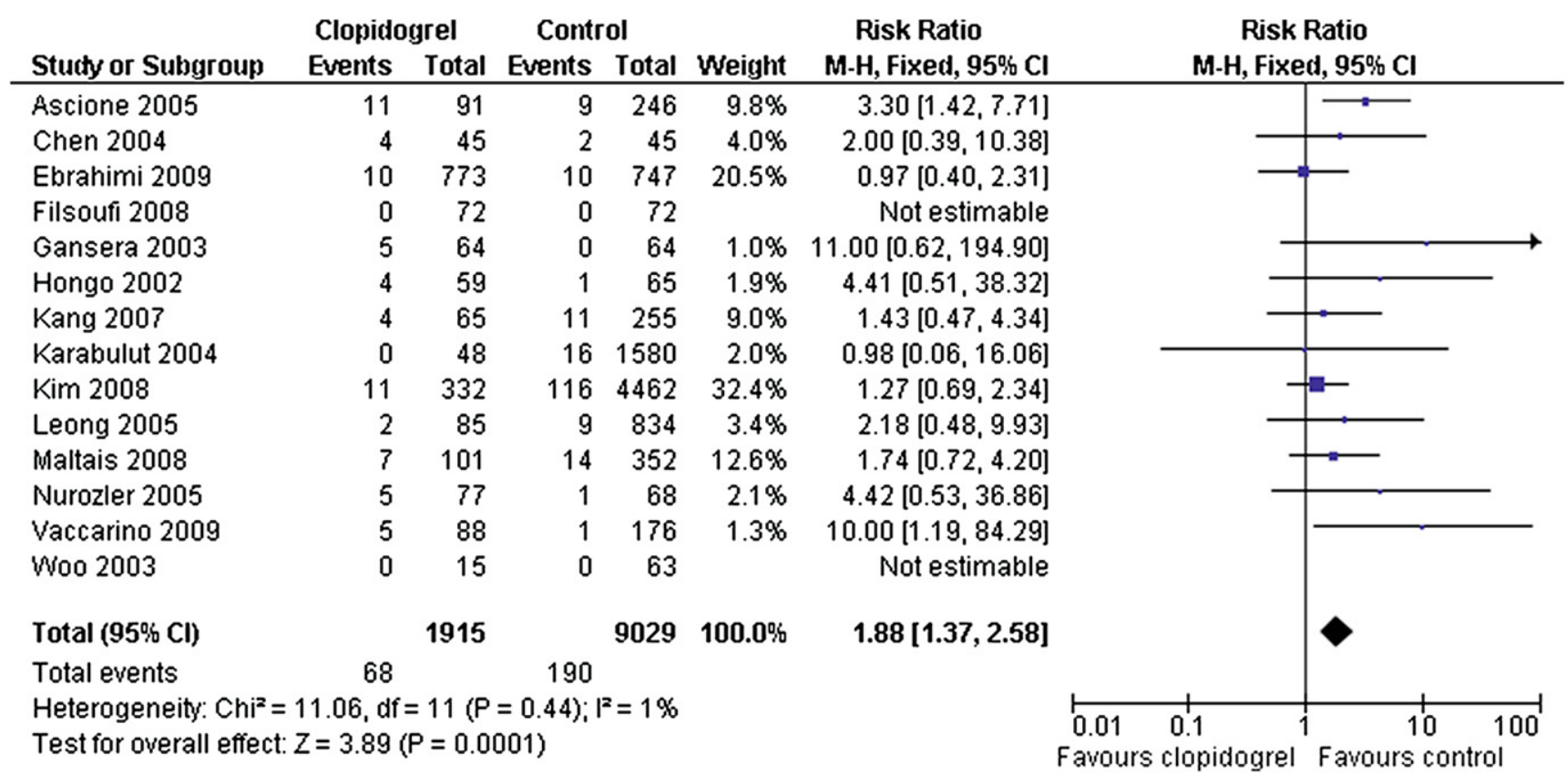

FIGURE 5. Pooled RR of reoperation for bleeding in patients who received clopidogrel before CABG versus controls (observational cohort studies only included). $C I$, Confidence interval. 


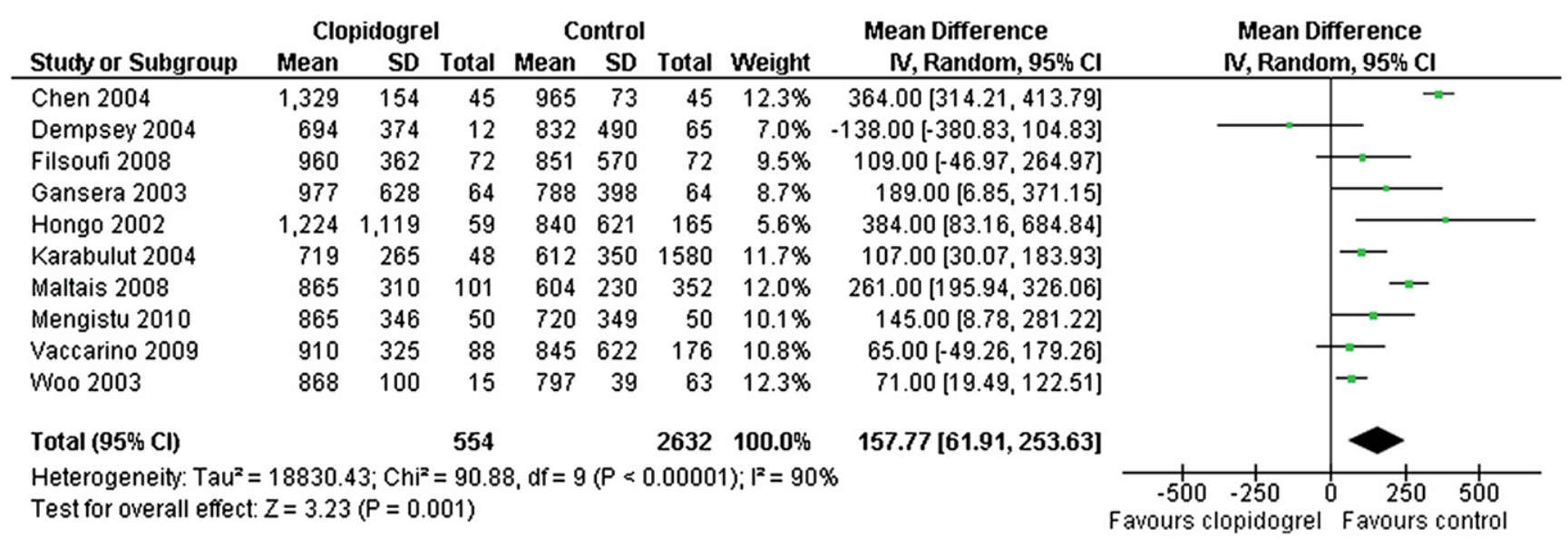

FIGURE 6. Weighted mean difference of drainage blood losses at 24 hours in patients who received clopidogrel before CABG versus controls (observational cohort studies only included). $C I$, Confidence interval.

The results of the present meta-analysis of data from prospective, randomized studies, with all the due limitations, provide evidence of a likely reduced risk of cardiovascular events immediately after CABG, which is in line with the findings after percutaneous coronary intervention. Although postoperative bleeding is of great concern in these patients, major bleeding defined by TIMI criteria was the only parameter of severe postoperative bleeding that we were able to evaluate from 2 prospective randomized trials, and we did not retrieve any data on the rate of resternotomy for bleeding. However, the TIMI criteria for major bleeding are strict ${ }^{10}$ and may have effectively encompassed those patients who underwent resternotomy.

On the other hand, meta-analysis of a larger study population (12,129 patients from 13 studies reporting on immediate postoperative mortality) as reported in observational studies, both prospective and retrospective, raises serious concerns regarding the safety of administration of clopidogrel immediately before surgical revascularization. Although we might have expected only an increased risk of bleeding in patients exposed to clopidogrel, we did not expect to observe a significantly increased risk of immediate postoperative death associated with this drug. This finding does not correlate with the observed reduced risk of postoperative myocardial infarction among patients who preoperatively received clopidogrel. However, the definition criteria of myocardial infarction after CABG may vary markedly from study to study, and its definition is difficult per se. The significantly increased risk of blood transfusion and resternotomy may explain the increased risk of death in these patients. Indeed, need of blood transfusion is associated with a significantly increased risk of immediate and intermediate mortality, ${ }^{21,22}$ and a recent analysis of the Society of Thoracic Surgeons National Cardiac Database

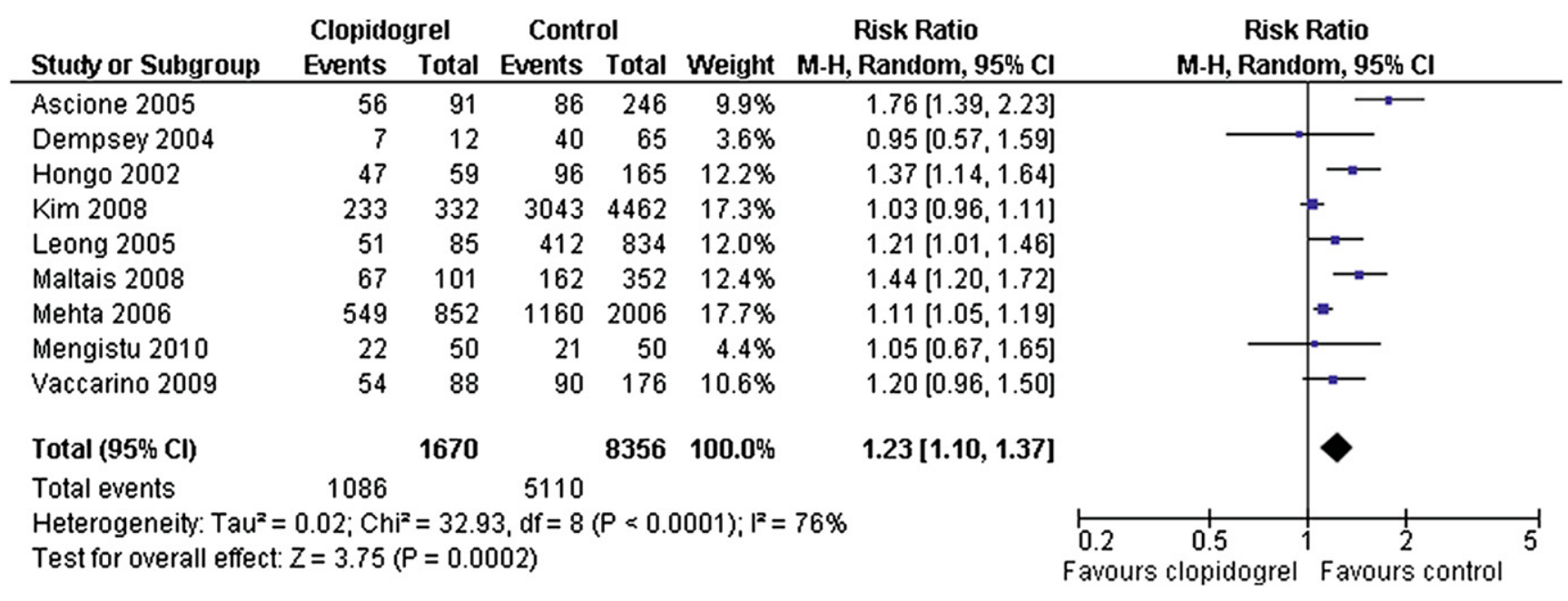

FIGURE 7. Pooled RR of postoperative packed red blood cells transfusion in patients who received clopidogrel before CABG versus controls (observational cohort studies only included). CI, Confidence interval. 


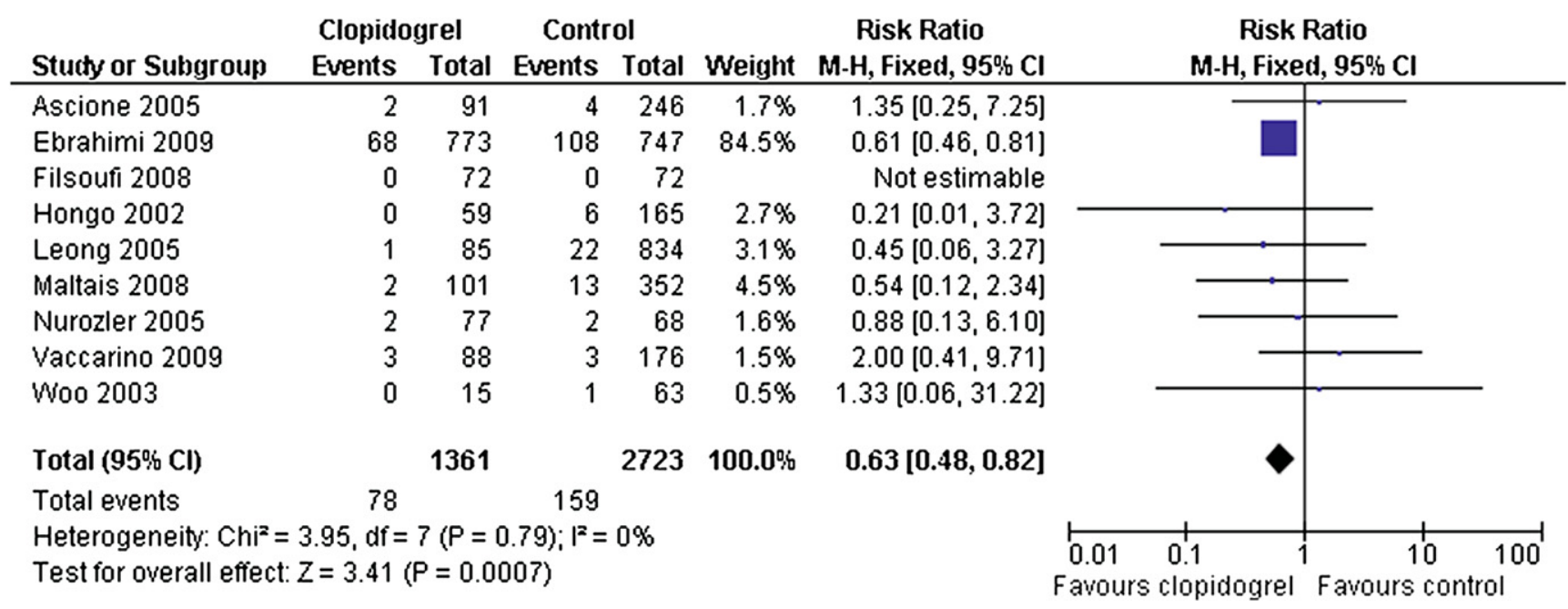

FIGURE 8. Pooled RR of immediate postoperative myocardial infarction in patients who received clopidogrel before CABG versus controls (observational cohort studies only included). $C I$, Confidence interval.

from 2004 to 2007 showed a 4.5-fold higher risk of mortality in patients requiring reoperation for bleeding $(9.1 \%$ vs $2.0 \%)^{23}$

\section{Study Limitations}

This study has several limitations related to the nature of the studies included. Because there are difficulties, ethical and otherwise, in performing a prospective randomized study on the preoperative use of clopidogrel in patients undergoing CABG, observational studies so far have largely failed to provide data from appropriately matched study groups. The inclusion in the control group of patients previously exposed to clopidogrel may result in a significant bias. This led us to exclude several large studies from this metaanalysis, whose results are otherwise in line with the present findings. ${ }^{6,7}$

There were no available data on the platelet inhibitory response to clopidogrel. Although this is certainly of major scientific and clinical importance, any comment on this issue would be speculative. A recent article did show that clopidogrel responsiveness predicted blood loss and transfusion requirement after off-pump CABG. ${ }^{24}$

These findings are not conclusive, but they do indicate that surgeons should more actively investigate the benefits and risks associated with preoperative use of clopidogrel and currently available more potent antiplatelet drugs in appropriate studies of better quality. This may allow guidelines that extend the benefits achieved in patients undergoing percutaneous coronary intervention to those requiring $\mathrm{CABG}$ with improved safety and possibly reduced costs.

\section{CONCLUSIONS}

The results of this study demonstrated that data on patients undergoing CABG after clopidogrel use are scanty and originate from studies with suboptimal design and analysis. Despite data from randomized trials showing a trend toward reduced cardiovascular complications, observational studies showed that patients with recent exposure to clopidogrel have a significantly increased risk of postoperative death, reoperations for bleeding, blood loss, and need of blood transfusions.

The authors thank Steven Steinhubl for suggestions and providing supplementary data for this meta-analysis.

\section{References}

1. Kushner FG, Hand M, Smith SC Jr, King SB 3rd, Anderson JL, Antman EM, et al. 2009 Focused Updates: ACC/AHA guidelines for the management of patients with ST-elevation myocardial infarction (updating the 2004 Guideline and 2007 Focused Update) and ACC/AHA/SCAI Guidelines on Percutaneous Coronary Intervention (updating the 2005 Guideline and 2007 Focused Update): a report of the American College of Cardiology Foundation/American Heart Association Task Force on Practice Guidelines. Circulation. 2009;120:2271-306.

2. Anderson JL, Adams CD, Antman EM, Bridges CR, Califf RM, Casey DE Jr, et al. ACC/AHA 2007 guidelines for the management of patients with unstable angina/non ST-elevation myocardial infarction: a report of the American College of Cardiology/American Heart Association Task Force on Practice Guidelines. Circulation. 2007;116:e148-304.

3. Steinhubl SR, Berger PB, Mann JT 3rd, Fry ET, DeLago A, Wilmer C, et al. Clopidogrel for the Reduction of Events During Observation. Early and sustained dual oral antiplatelet therapy following percutaneous coronary intervention: a randomized controlled trial. JAMA. 2002;288:2411-20.

4. Mehta RH, Chen AY, Pollack CV Jr, Roe MT, Zalenski RJ, Clements EA, et al. Challenges in predicting the need for coronary artery bypass grafting at presentation in patients with non-ST-segment elevation acute coronary syndromes. Am J Cardiol. 2006;98:624-7.

5. Higgins JPT, Altman DG on behalf of the Cochrane Statistical Methods Group and the Cochrane Bias Methods Group, eds. In: Higgins JPT, Green S, eds. Assessing risk of bias in included studies. Cochrane Handbook for Systematic Reviews of Interventions Version 5.0.0 (updated September 2008). The Cochrane Collaboration, 2008. Available at www.cochrane-handbook.org.

6. Berger JS, Frye CB, Harshaw Q, Edwards FH, Steinhubl SR, Becker RC. Impact of clopidogrel in patients with acute coronary syndromes requiring coronary artery bypass surgery: a multicenter analysis. J Am Coll Cardiol. 2008;52: 1693-701.

7. Kapetanakis EI, Medlam DA, Boyce SW, Haile E, Hill PC, Dullum MK, et al. Clopidogrel administration prior to coronary artery bypass grafting surgery: 
the cardiologist's panacea or the surgeon's headache? Eur Heart J. 2005;26: 576-83.

8. Fergusson DA, Hébert PC, Mazer CD, Fremes S, MacAdams C, Murkin JM, et al. A comparison of aprotinin and lysine analogues in high-risk cardiac surgery. N Engl J Med. 2008;358:2319-31.

9. Wells GA, Shea B, O'Connell D, Peterson J, Welch V, Losos M, et al. The Newcastle-Ottawa Scale (NOS) for assessing the quality of nonrandomised studies in meta-analyses. Available at: http://www.ohri.ca/programs/clinical_ epidemiology/oxford.htm. Accessed July 22, 2010.

10. Bovill EG, Terrin ML, Stump DC, Berke AD, Frederick M, Collen D, et al. Hemorrhagic events during therapy with recombinant tissue-type plasminogen activator, heparin, and aspirin for acute myocardial infarction. Results of the Thrombolysis in Myocardial Infarction (TIMI), Phase II Trial. Ann Intern Med. 1991;115:256-65.

11. Fox KA, Mehta SR, Peters R, Zhao F, Lakkis N, Gersh BJ, et al. Benefits and risks of the combination of clopidogrel and aspirin in patients undergoing surgical revascularization for non-ST-elevation acute coronary syndrome: the Clopidogrel in Unstable angina to prevent Recurrent ischemic Events (CURE) Trial. Circulation. 2004;110:1202-8.

12. McLean DS, Sabatine MS, Guo W, McCabe CH, Cannon CP. Benefits and risks of clopidogrel pretreatment before coronary artery bypass grafting in patients with ST-elevation myocardial infarction treated with fibrinolytics in CLARITY-TIMI 28. J Thromb Thrombolysis. 2007;24:85-91.

13. Saw J, Topol EJ, Steinhubl SR, Brennan D, Berger PB, Moliterno DJ, CREDO Investigators. Comparison of long-term usefulness of clopidogrel therapy after the first percutaneous coronary intervention or coronary artery bypass grafting versus that after the second or repeat intervention. Am J Cardiol. 2004;94: 623-5.

14. Sabatine MS, Cannon CP, Gibson CM, López-Sendón JL, Montalescot G, Theroux $\mathrm{P}$, et al. Addition of clopidogrel to aspirin and fibrinolytic therapy for myocardial infarction with ST-segment elevation. $N$ Engl J Med. 2005;352: 1179-89.

15. Yusuf S, Zhao F, Mehta SR, Chrolavicius S, Tognoni G, Fox KK, Clopidogrel in Unstable Angina to Prevent Recurrent Events Trial Investigators. Effects of clo- pidogrel in addition to aspirin in patients with acute coronary syndromes withou ST-segment elevation. $N$ Engl J Med. 2001;345:494-502.

16. Austin PC. Primer on statistical interpretation or methods report card on propensity-score matching in the cardiology literature from 2004 to 2006: a systematic review. Circ Cardiovasc Qual Outcomes. 2008;1:62-7.

17. Vaccarino GN, Thierer J, Albertal M, Vrancic M, Piccinini F, Benzadón M, et al Impact of preoperative clopidogrel in off pump coronary artery bypass surgery: a propensity score analysis. J Thorac Cardiovasc Surg. 2009;137:309-13.

18. Kapetanakis EI, Medlam DA, Petro KR, Haile E, Hill PC, Dullum MK, et al. Effect of clopidogrel premedication in off-pump cardiac surgery: are we forfeiting the benefits of reduced hemorrhagic sequelae? Circulation. 2006;113:1667-74.

19. Song SW, Youn YN, Yi G, Lee S, Yoo KJ. Effects of continuous administration of clopidogrel before off-pump coronary artery bypass grafting in patients with acute coronary syndrome. Circ J. 2008;72:626-32.

20. Filsoufi F, Rahmanian PB, Castillo JG, Kahn RA, Fischer G, Adams DH. Clopidogrel treatment before coronary artery bypass graft surgery increases postoperative morbidity and blood product requirements. J Cardiothorac Vasc Anesth. 2008;22:60-6.

21. Koch CG, Li L, Duncan AI, Mihaljevic T, Cosgrove DM, Loop FD, et al. Morbidity and mortality risk associated with red blood cell and blood-component transfusion in isolated coronary artery bypass grafting. Crit Care Med. 2006; 34:1608-16

22. Kuduvalli M, Oo AY, Newall N, Grayson AD, Jackson M, Desmond MJ, et al. Effect of peri-operative red blood cell transfusion on 30-day and 1-year mortality following coronary artery bypass surgery. Eur J Cardiothorac Surg. 2005;27: 592-8.

23. Mehta RH, Sheng S, O'Brien SM, Grover FL, Gammie JS, Ferguson TB, et al Reoperation for bleeding in patients undergoing coronary artery bypass surgery: incidence, risk factors, time trends, and outcomes. Circ Cardiovasc Qual Out comes. 2009;2:583-90

24. Kwak YL, Kim JC, Choi YS, Yoo KJ, Song Y, Shim JK. Clopidogrel responsiveness regardless of the discontinuation date predicts increased blood loss and transfusion requirement after off-pump coronary artery bypass graft surgery. $J$ Am Coll Cardiol. 2010;56:1994-2002. 


\section{E-References}

E1. Ascione R, Ghosh A, Rogers CA, Cohen A, Monk C, Angelini GD. In-hospital patients exposed to clopidogrel before coronary artery bypass graft surgery: a word of caution. Ann Thorac Surg. 2005;79:1210-6.

E2. Chen L, Bracey AW, Radovancevic R, Cooper JR Jr, Collard CD, Vaughn WK, et al. Clopidogrel and bleeding in patients undergoing elective coronary artery bypass grafting. J Thorac Cardiovasc Surg. 2004;128:425-31.

E3. Dempsey CM, Lim MS, Stacey SG. A prospective audit of blood loss and blood transfusion in patients undergoing coronary artery bypass grafting after clopidogrel and aspirin therapy. Crit Care Resusc. 2004;6:248-52.

E4. Ebrahimi R, Dyke C, Mehran R, Manoukian SV, Feit F, Cox DA, et al. Outcomes following pre-operative clopidogrel administration in patients with acute coronary syndromes undergoing coronary artery bypass surgery: the ACUITY (Acute Catheterization and Urgent Intervention Triage strategY) trial. J Am Coll Cardiol. 2009;53:1965-72.

E5. Filsoufi F, Rahmanian PB, Castillo JG, Kahn RA, Fischer G, Adams DH. Clopidogrel treatment before coronary artery bypass graft surgery increases postoperative morbidity and blood product requirements. J Cardiothorac Vasc Anesth. 2008;22:60-6.

E6. Gansera B, Schmidtler F, Spiliopoulos K, Angelis I, Neumaier-Prauser P, Kemkes BM. Urgent or emergent coronary revascularization using bilateral internal thoracic artery after previous clopidogrel antiplatelet therapy. Thorac Cardiovasc Surg. 2003;51:185-9.

E7. Hongo RH, Ley J, Dick SE, Yee RR. The effect of clopidogrel in combination with aspirin when given before coronary artery bypass grafting. J Am Coll Cardiol. 2002;40:231-7.

E8. Kang W, Theman TE, Reed JF 3rd, Stoltzfus J, Weger N. The effect of preoperative clopidogrel on bleeding after coronary artery bypass surgery. J Surg Educ. 2007;64:88-92.
E9. Karabulut H, Toraman F, Evrenkaya S, Goksel O, Tarcan S, Alhan C. Clopidogrel does not increase bleeding and allogenic blood transfusion in coronary artery surgery. Eur J Cardiothorac Surg. 2004;25:419-23.

E10. Kim JH, Newby LK, Clare RM, Shaw LK, Lodge AJ, Smith PK, et al. Clopidogrel use and bleeding after coronary artery bypass graft surgery. Am Heart J. 2008;156:886-92.

E11. Leong JY, Baker RA, Shah PJ, Cherian VK, Knight JL. Clopidogrel and bleeding after coronary artery bypass graft surgery. Ann Thorac Surg. 2005;80: 928-33.

E12. Maltais S, Perrault LP, Do QB. Effect of clopidogrel on bleeding and transfusions after off-pump coronary artery bypass graft surgery: impact of discontinuation prior to surgery. Eur J Cardiothorac Surg. 2008;34:127-31.

E13. Mehta RH, Roe MT, Mulgund J, Ohman EM, Cannon CP, Gibler WB, et al. Acute clopidogrel use and outcomes in patients with non-ST-segment elevation acute coronary syndromes undergoing coronary artery bypass surgery. $\mathrm{J} \mathrm{Am}$ Coll Cardiol. 2006;48:281-6.

E14. Mengistu AM, Mayer J, Boldt J, Röhm KD, Suttner SW. Usefulness of monitoring platelet function by multiple electrode aggregometry in primary coronary artery bypass surgery. J Cardiothorac Vasc Anesth. 2011;25:42-7. Epub 2010 Apr 27.

E15. Nurozler F, Kutlu T, Küçük G, Okten C. Impact of clopidogrel on postoperative blood loss after non-elective coronary bypass surgery. Interact Cardiovasc Thorac Surg. 2005;4:546-9.

E16. Vaccarino GN, Thierer J, Albertal M, Vrancic M, Piccinini F, Benzadón M, et al. Impact of preoperative clopidogrel in off pump coronary artery bypass surgery: a propensity score analysis. J Thorac Cardiovasc Surg. 2009;137:309-13.

E17. Woo YJ, Grand T, Valettas N. Off-pump coronary artery bypass grafting attenuates postoperative bleeding associated with preoperative clopidogrel administration. Heart Surg Forum. 2003;3:282-5. 
TABLE E1. Excluded studies from meta-analysis on the effects of clopidogrel before coronary artery bypass surgery

\section{Studies}

1. Akowuah E, Shrivastava V, Jamnadas B, Hopkinson D, Sarkar P, Storey $\mathrm{R}$, et al. Comparison of two strategies for the management of antiplatelet therapy during urgent surgery. Ann Thorac Surg. 2005;80:149-52.

2. Badreldin A, Kroener A, Kamiya H, Lichtenberg A, Hekmat K. Effect of clopidogrel on perioperative blood loss and transfusion in coronary artery bypass graft surgery. Interact Cardiovasc Thorac Surg. 2010;10:48-52.

3. Berger JS, Frye CB, Harshaw Q, Edwards FH, Steinhubl SR, Becker RC. Impact of clopidogrel in patients with acute coronary syndromes requiring coronary artery bypass surgery: a multicenter analysis. J Am Coll Cardiol. 2008;52:1693-701.

4. Blasco-Colmenares E, Perl TM, Guallar E, Baumgartner WA, Conte JV, Alejo D, et al. Aspirin plus clopidogrel and risk of infection after coronary artery bypass surgery. Arch Intern Med. 2009;169:788-96.

5. Chew DP, Huang Z, Pieper KS, White H, Mahaffey KW, Ferguson JJ, et al. Patients with non-ST-elevation acute coronary syndromes undergoing coronary artery bypass grafting in the modern era of antithrombotic therapy. Am Heart J. 2008;155:239-44.

5. Chu MW, Wilson SR, Novick RJ, Stitt LW, Quantz MA. Does clopidogrel increase blood loss following coronary artery bypass surgery? Ann Thorac Surg. 2004;78:1536-41.

6. Englberger L, Faeh B, Berdat PA, Eberli F, Meier B, Carrel T. Impact of clopidogrel in coronary artery bypass grafting. Eur J Cardiothorac Surg. 2004;26:96-101.

7. Firanescu CE, Martens EJ, Schönberger JP, Soliman Hamad MA, van Straten AH. Postoperative blood loss in patients undergoing coronary artery bypass surgery after preoperative treatment with clopidogrel. A prospective randomized controlled study. Eur J Cardiothorac Surg. 2009;36:856-62.

8. Herman CR, Buth KJ, Kent BA, Hirsch GM. Clopidogrel increases blood transfusion and hemorrhagic complications in patients undergoing cardiac surgery. Ann Thorac Surg. 2010;89:397-402.

9. Kapetanakis EI, Medlam DA, Boyce SW, Haile E, Hill PC, Dullum MK, et al. Clopidogrel administration before coronary artery bypass grafting surgery: the cardiologist's panacea or the surgeon's headache? Eur Heart J. 2005;26:576-83.

10. Kapetanakis EI, Medlam DA, Petro KR, Haile E, Hill PC, Dullum MK, et al. Effect of clopidogrel premedication in off-pump cardiac surgery: are we forfeiting the benefits of reduced hemorrhagic sequelae? Circulation. 2006;113:1667-74.

11. Nesher N, Singh SK, Fawzy HF, Sever JY, Goldman BE, Cohen GN, et al. Impact of clopidogrel use on mortality and major bleeding in patients undergoing coronary artery bypass surgery. Interact Cardiovasc Thorac Surg. 2010;10:732-6.

12. Ouattara A, Bouzguenda H, Le Manach Y, Léger P, Mercadier A, Leprince $\mathrm{P}$, et al. Impact of aspirin with or without clopidogrel on postoperative bleeding and blood transfusion in coronary surgical patients treated prophylactically with a low-dose of aprotinin. Eur Heart J. 2007;28:1025-32.

13. Pothula S, Sanchala VT, Nagappala B, Inchiosa MA Jr. The effect of preoperative antiplatelet/anticoagulant prophylaxis on postoperative blood loss in cardiac surgery. Anesth Analg. 2004;98:4-10.

14. Preisman S, Kogan A, Itzkovsky K, Leikin G, Raanani E. Modified thromboelastography evaluation of platelet dysfunction in patients undergoing coronary artery surgery. Eur J Cardiothorac Surg. 2010;37:1367-74

\section{Reasons for exclusion from present meta-analysis}

No valid control group, and aprotinin was used only in the clopidogrel group.

Use of aprotinin in most patients.

Some control patients received clopidogrel before surgery, and it was discontinued $>5 \mathrm{~d}$ before surgery. Aprotinin administered in $>31 \%$ of patients.

Valve surgery included in the analysis.

No retrievable data.

Use of aprotinin in most patients; no valid control group.

Use of aprotinin in all patients.

All patients were exposed to clopidogrel.

Valve surgery included in the analysis.

Some control patients received clopidogrel before surgery and discontinued $>7 \mathrm{~d}$ before surgery.

Some control patients received clopidogrel before surgery, and it was discontinued $>7 \mathrm{~d}$ before surgery; it is a post hoc analysis of a previously published series.

Aprotinin was administered to patients exposed to clopidogrel.

Use of aprotinin in all patients.

No valid control group.

No valid study groups. 
Studies

15. Ray JG, Deniz S, Olivieri A, Pollex E, Vermeulen MJ, Alexander KS, et al. Increased blood product use among coronary artery bypass patients prescribed preoperative aspirin and clopidogrel. BMC Cardiovasc Disord. 2003;3:3.

16. Reichert MG, Robinson AH, Travis JA, Hammon JW, Kon ND, et al. Effects of a waiting period after clopidogrel treatment before performing coronary artery bypass grafting. Pharmacotherapy. 2008;28:151-5.

17. Shim JK, Choi YS, Oh YJ, Bang SO, Yoo KJ, Kwak YL. Effects of preoperative aspirin and clopidogrel therapy on perioperative blood loss and blood transfusion requirements in patients undergoing off-pump coronary artery bypass graft surgery. J Thorac Cardiovasc Surg. 2007; 134:59-64.

18. Song SW, Youn YN, Yi G, Lee S, Yoo KJ. Effects of continuous administration of clopidogrel before off-pump coronary artery bypass grafting in patients with acute coronary syndrome. Circ J. 2008; 72:626-32.

19. Velik-Salchner C, Maier S, Innerhofer P, Kolbitsch C, Streif W, Mittermayr M, et al. An assessment of cardiopulmonary bypass-induced changes in platelet function using whole blood and classical light transmission aggregometry: the results of a pilot study. Anesth Analg. 2009; 108:1747-54.

20. von Heymann C, Redlich U, Moritz M, Sander M, Vargas Hein O, Grubitzsch H, et al. Aspirin and clopidogrel taken until 2 days before coronary artery bypass graft surgery is associated with increased postoperative drainage loss. Thorac Cardiovasc Surg. 2005;53:341-5.

21. Yende S, Wunderink RG. Effect of clopidogrel on bleeding after coronary artery bypass surgery. Crit Care Med. 2001;29:2271-5.

22. Øvrum E, Tangen G, Tølløfsrud S, Ringdal MA, Øystese R, Istad R. Low postoperative dose of aprotinin reduces bleeding and is safe in patients receiving clopidogrel before coronary artery bypass surgery. A prospective randomized study. Interact Cardiovasc Thorac Surg. 2010;10:545-8.
Reasons for exclusion from present meta-analysis

No retrievable data.

All patients were exposed to clopidogrel.

All patients were exposed to clopidogrel.

All patients were exposed to clopidogrel.

Aprotinin was administered to all patients.

No valid control group.

Valve surgery included in the analysis.

All patients were exposed to clopidogrel. 
TABLE E2. Results of systematic review of studies using propensity score analysis on the effects of clopidogrel before coronary artery bypass surgery: Appropriate use of propensity-matched analysis is categorized according to Austin's criteria*

\begin{tabular}{|c|c|c|}
\hline Studies & $\begin{array}{l}\text { Propensity-matched } \\
\text { analysis }\end{array}$ & Appropriateness of propensity-matched analysis* \\
\hline $\begin{array}{l}\text { 1. Blasco-Colmenares E, Perl TM, Guallar E, Baumgartner } \\
\text { WA, Conte JV, Alejo D, et al. Aspirin plus clopidogrel and } \\
\text { risk of infection after coronary artery bypass surgery. Arch } \\
\text { Intern Med. } 2009 ; 169: 788-96 \text {. }\end{array}$ & No & - \\
\hline $\begin{array}{l}\text { 2. Vaccarino GN, Thierer J, Albertal M, Vrancic M, Piccinini } \\
\text { F, Benzadón M, et al. Impact of preoperative clopidogrel } \\
\text { in off pump coronary artery bypass surgery: a propensity } \\
\text { score analysis. J Thorac Cardiovasc Surg. 2009;137:309- } \\
\text { 13. }\end{array}$ & Yes & $\begin{array}{l}\text { - Propensity matching: no information } \\
\text { - Assessing balance between study groups: no } \\
\text { - Estimating the effect of treatment on the outcome: no }\end{array}$ \\
\hline $\begin{array}{l}\text { 3. Kim JH, Newby LK, Clare RM, Shaw LK, Lodge AJ, } \\
\text { Smith PK, et al. Clopidogrel use and bleeding after } \\
\text { coronary artery bypass graft surgery. Am Heart J. } \\
2008 ; 156: 886-92 \text {. }\end{array}$ & No & - \\
\hline $\begin{array}{l}\text { 4. Song SW, Youn YN, Yi G, Lee S, Yoo KJ. Effects of } \\
\text { continuous administration of clopidogrel before off-pump } \\
\text { coronary artery bypass grafting in patients with acute } \\
\text { coronary syndrome. Circ J. 2008;72:626-32. }\end{array}$ & Yes & $\begin{array}{l}\text { - Propensity matching: no information } \\
\text { - Assessing balance between study groups: yes } \\
\text { - Estimating the effect of treatment on the outcome: no }\end{array}$ \\
\hline $\begin{array}{l}\text { 5. Ouattara A, Bouzguenda H, Le Manach Y, Léger P, } \\
\text { Mercadier A, Leprince P, et al. Impact of aspirin with or } \\
\text { without clopidogrel on postoperative bleeding and blood } \\
\text { transfusion in coronary surgical patients treated } \\
\text { prophylactically with a low-dose of aprotinin. Eur Heart } \\
\text { J. 2007;28:1025-32. }\end{array}$ & No & - \\
\hline $\begin{array}{l}\text { 6. Kapetanakis EI, Medlam DA, Petro KR, Haile E, Hill PC, } \\
\text { Dullum MK, et al. Effect of clopidogrel premedication in } \\
\text { off-pump cardiac surgery: are we forfeiting the benefits of } \\
\text { reduced hemorrhagic sequelae? Circulation. } \\
\text { 2006;113:1667-74. }\end{array}$ & $\begin{array}{c}\text { Yes } \\
\text { (subanalysis of study no. 7) }\end{array}$ & - \\
\hline $\begin{array}{l}\text { 7. Kapetanakis EI, Medlam DA, Boyce SW, Haile E, Hill PC, } \\
\text { Dullum MK, et al. Clopidogrel administration before } \\
\text { coronary artery bypass grafting surgery: the cardiologist's } \\
\text { panacea or the surgeon's headache? Eur Heart J. } \\
2005 ; 26: 576-83 \text {. }\end{array}$ & Yes & $\begin{array}{l}\text { - Propensity matching: no information } \\
\text { - Assessing balance between study groups: no } \\
\text { - Estimating the effect of treatment on the outcome: yes }\end{array}$ \\
\hline
\end{tabular}

